\title{
Quasi-Competitiveness of the Audit Services Market in Ukraine: The Aspect of European Integration
}

Inna Makarenko

Sumy State University

\author{
Oleksiy Plastun \\ Sumy State University
}

\section{ABSTRACT}

In the context of European integration processes and transformations in the banking sector, a study of the concentration of the audit services market in Ukraine, one of the most regulated markets, was held. The authors applied a number of methods for evaluation of concentration: the traditional methods of determining the level of market competition and the Kruskal-Wallis test to confirm market heterogeneity. The results allow for a conclusion that there is a high level of regional market concentration, which necessitates a competitive market environment for the implementation of audit services.

\section{JEL Codes: M4, M40, M41, M42, M49}

Keywords: audit services market, competition, concentration

\section{INTRODUCTION}

A professional audit opinion on the financial statements of companies in the real sector, banking sector, and intermediaries of the financial markets is not only the basis for economic decision making for investors, shareholders, and other stakeholders, but also a guarantee of the stable functioning of these particular economic agents and related sectors in general.

For example, during the large-scale transformation in the banking sector of Ukraine accompanied by the withdrawal from the market of a number of banks, the interests not only of shareholders, but also of ordinary depositors, were threatened, given the discrepancy of the real solvency of banks' data specified in their audited financial statements. However, questions arise as to the adequacy of positive audit reports given for these institutions and where proper audit regulation was ensured.

Despite some attempts to reform approaches to the regulation of the audit profession in the context of the implementation of the provisions of Directive 2014/56/EU and Regulation (16 April 2014), and with the adoption of legislation projects by the Ministry of Finance of Ukraine On the Audit of Financial Statements and Audit Activity of 17 August 2015 and On Auditing of 10 June 2015, certain regulations in the sector of public enterprises and financial intermediation, on our opinion, have a destructive effect on the competitive environment in the audit services market e 640 On Approval of the Maintenance of the Register of Audit Firms and Auditors to Conduct Audits of Financial Institutions (26 February 2013), which ratifies discriminating conditions or registration of auditors and audit firms that can conduct audits of financial institutions and Law No. 390 of the Cabinet of Ministers of Ukraine of 4 June 2015 On Some Issues of Financial Statements Audit of Public Sector Companies, which approved the criteria which involve an accounting firm's audit of the financial statements or the consolidated financial statements of some large public sector companies.

The stated Resolution and Act introduce artificial restrictive conditions for the audit of public companies and major financial institutions only by major players in the audit market, including the Big 4 firms and other international networks.

The discriminatory nature of these documents and the conditions they set appear in the artificial restriction of access to auditing by medium and small audit firms to financial institutions because of the need for additional expensive training and the introduction of explicit preferences for international audit brands (especially the Big $4^{1}$ ), which demonstrate a unique matching to the specified criteria and conditions to test public companies.

For example, Law No. 390 of the Cabinet of Ministers of Ukraine On Some Issues of Financial Statements Audit of Public Sector Companies of 4 June 2015 divides public companies in terms of assets into two groups. Depending on the membership of one of these groups, audit firms involved in the audit must comply with certain restrictive covenants (the number of employees who are directly involved in providing audit services must have a certificate as an independent auditor of Ukraine

${ }^{1}$ The four largest companies in the world providing auditing and consulting services: Deloitte, Ernst \& Young, PricewaterhouseCoopers, and KPMG. 
or a document certifying a full program of independent certification, the amount of annual income of the audit firm during the past three years, and the availability of an insurance contract to third parties for a certain amount). Thus, the implementation of these covenants obviously favors only Big 4 firms and other major international networks.

By supporting the importance of normalization procedures for audit of financial institutions and public companies in restructuring audit activities, it should be noted that narrowing market competition with the adoption of these documents shall have a primarily negative effect on the possibility of equal access by audit companies, which operate in different market segments to individual customers.

However, authoritative studies, including ACCA (2011), show that the basis of the development of competitive markets and audit services, as well as new entrants to these markets, is the cancellation of these discriminatory covenants.

The development of such opinions is included in a report by the Commission on competition, Competition Commission (2013) UK, which is studying the experiences of audit companies of the FTSE 100 and FTSE 250. It concluded that $31 \%$ of FTSE 100 companies and 20\% FTSE 250 companies had the same auditor from Big 4 companies for over 20 years, and $67 \%$ of FTSE 100 companies and $52 \%$ of FTSE 250 companies for over ten years. In this regard, requirements for auditor rotation to ensure market competition are vital. Now, according to the Commission, the establishment of discriminatory covenants in favor of Big 4 companies must be forbidden, though for middle tier audit companies (BDO, Grant Thornton,) the following criteria in investment or credit agreements are not insurmountable.

Moreover, in the context of harmonization of national legislation with the provisions of Directive 2014/56/EU and Regulation (16 April 2014), according to Article 21 Professional Ethics and Skepticism, Article 22b Preparation for the Statutory Audit and Assessment of Threats to Independence, and Article 27 Statutory Audit of Consolidated Financial Statements, questions of competition based on price or willingness to compromise in a contractual relationship with the client, but not quality assurance, has a significant importance in the context of auditor independence, the quality of services, and restoration of confidence in financial reporting and audit in general.

Approaches to the study of competition in the audit services market in the world vary in terms of direct impact on the market concentration on key parameters: price, quality assurance, methods for determining such concentrations, and levels of study. As for Ukraine, it is worth noting that the lack of systematic research in the field of competition of audit services is embodied in the lack of a unified strategy of the Auditing Chamber of Ukraine and the Ministry of Finance of Ukraine as for its further development and reforms necessary at this stage in the context of the implementation of EU standards on regulation of audit and protection of the interests of users of audited financial statements.

The hypothesis put forward by the authors on the nature of the quasi-competitive market for audit services in Ukraine according to the volume of services provided and cost parameters seems to be obvious at first glance. The calculation results indicate the presence of two segments in the audit services market in Ukraine: a competitive segment of national audit practices and a highly concentrated segment of the world's largest audit networks. The proof for the hypothesis is based on the results of calculations of certain indicators of market power and systematic tests of homogeneity of the market environment.

The structure of the paper provides an overview of research sources and regulatory materials in the next section, Section 3 includes data definitions and the methodology of the study of market concentration, Section 4 reveals empirical results, and Section 5 contains conclusions and recommendations.

\section{SCIENTIFIC SOURCES REVIEW}

\subsection{Regulatory initiatives to promote competition in the audit services market}

Research of competition for audit services is subject to the attention of regulators around the world because of the undeniable importance that the quality of audit financial statements is systemically important for companies and financial institutions, it is in the interests of users of accounting and audit firms, and they have an actualization role in maintaining the transparency and stability of their economies in a post-crisis period.

Thus, the European Commission released a "Green Paper" (EC Green Paper, 2010), in which the question of "systemic risk" is associated with the concentration of audit services in the Big 4 segment and the possible conversion of the four largest companies to three which occupy a prominent place. In 2014, the issue of competition in the audit services market received legislative confirmation in the provisions of Directive 2014/56/EU and Regulation (16 April 2014), which complements the requirements of Directive 2006/43/EU. 
The Oxera study (2006) provides evidence that an increase in the concentration of audit firms can raise fees for rendered services. However, it was also proven that audit committees are focused primarily on the quality and reputation of audit firms, rather than on price parameters. In addition, it is difficult to distinguish between the impact of market concentration on price and other regulatory requirements.

Requests to the Office of Fair Trading on the state of competition in the audit services market and the dominance of the Big 4 were carried out by the Economic Affairs Committee of the House of Lords. The final report of the House of Lords (2010) did not confirm a direct link between lower quality audit with increasing concentration of audit firms, but much criticism has resulted in certification of audit companies concentrated in the UK Financial Services segment during the last financial crisis.

These initiatives also emerged in the USA. Specifically, the oversight board for public companies (Public Company Accounting Oversight Board) and the US Senate are working on the current model of professional auditing activities and its role in preventing new financial crises, and the implementation of mandatory rotation of audit firms to ensure proper audit independence in the interests of shareholders.

The issue of concentration of the audit industry in the US in the context of its efficiency, sustainable development, and audit of large public companies is also the subject of US Treasury (2006) and Securities and Exchange Commission (2005) studies.

Reports by the Government Accountability Office (GAO, 2003, 2008) also paid great attention to the concentration of firms providing professional services and confirmed the hypothesis that a tight oligopolistic market structure creates conditions for the existence of price competition. In addition to the previous report in 2008, management (GAO, 2008) indicated that the increase in the concentration in the audit industry has a significant impact on the compensation paid to the auditors of the largest public companies.

A supranational organization that brings together highly qualified specialists who provide professional services (ACCA, 2011) also highlights the benefits of the extension of competition and the abolition of barriers for smaller audit firms on audit services. However, its representatives have warned that artificial intervention in the market environment with installation requirements for the restructuring of large audit firms cannot be positively evaluated.

The professional organization of UK specialists in management accounting (CIMA, 2010) examined a number of factors that contributed to the significant concentration of audit firms (complexity of audit standards, requirements for global coverage, significant infrastructure of global investments, and reputational risks for clients when attracting an auditor not from the Big 4).

Moreover, its experts say that despite these factors, the market for audit services is competitive. However, further reductions among major market players could lead to a catastrophic reduction in competition and conflicts of interest, and thus is undesirable.

The Organization for Economic Cooperation and Development (OECD, 2009, 2010) encourages promotion of competition in statutory audit and encourages expansion of intermediate accounting networks.

As you can see, the importance of competition in the audit services market is in the interests of key stakeholder groups keenly discussed by regulators in individual countries and at the supranational level. However, at the regulatory level, there is no consensus on the possibility of achieving free competition in these markets and the impact of existing market concentration on key parameters of audit services.

\subsection{Approaches to the study of the market concentration of audit services in the academic literature}

Existing approaches of scientists and official regulators are also polar. A large amount of scientific sources are dedicated to the study of the concentration of large firms in particular and competition in the audit services market in general, and can be structured in the following directions:

1. The study of the relationship between competition and different variables: fees for audit services, the quality of audit services, mandatory rotation of auditors;

2. Further consolidation of audit firms and changes in the competitive environment associated with changes from 5 to 4,4 to 3 ;

3. Distribution of scientific works by level - local sector, country level;

4. The study of methodologies to measure market concentration and market volume.

As to the first direction, it should be emphasized that the study of competition in the audit market is generally conducted in works of Doogar and Easley (1998), and is consistent with the GAO opinion on the possibility of the existence of competition in an oligopolistic market structure. 
It is also worth noting that Petrakov (2013) has a similar trend by using market analysis of audit services in Ukraine with the theory of quasi-competitive (industry) markets, which was developed by Baumol W.J. et al. (1982).

However, quasi-competitive markets in the works of Petrakov (2013) and Ohorodnikova (2013) are referred to as markets, which are a small number of large firms created under conditions that cause them to act competitively. In addition, these markets can combine high concentration of services in certain segments of certain features of other competitive markets.

The significant concentration of audit firms and audit order value differentiation in regional markets in the context of the overall analysis of the audit services market was also stated in the study of Redko (2009).

While acknowledging the qualitative analysis of competition in the audit services of Ukraine held by the last two authors, it is important to note that quantifiable statistical tests of concentration in this market were not taken.

In the context of the study of the relationship (both negative and positive) between the level of market concentration of audit services and audit of key parameters, it necessary to emphasize the considerable range of differences of scientific results since the studies were conducted by different authors, as well as in one study.

Thus, the results of studies of the effect of concentration of audit firms on the quality of information on corporate profits, which are checked, Francis et al. (2013), were as follows:

1) The quality of this information was positively related to the size of the total share of the Big 4 in the country compared with the share of non-Big 4 auditors;

2) A further increase of the concentration of Big 4 companies, especially with the dominance of one or two of these companies, leads to an increase in accrued reserves (provisions) in the accounts of clients tested, a low probability of their advertising, and delayed their recognition. According to the authors, it was discovered that regulators should focus not only on the extent of the Big 4 market, but also on the qualitative structure of this share.

As in previous work, Boone et al. (2012) suggest that increased concentration in the audit market leads to a lower quality of audit.

The work of Casterella et al. (2004) proved that there is a negative impact of competitive pressures on the performance of auditors from the position of their client regarding concepts of continuity and quality of income on an accrual basis and quality of audit.

In a positive meaning, the focus on local audit services markets is revised in the works of Numan and Willekens (2012) and Newton et al. (2013): The higher the concentration, the lower the fee for audit services and the fewer adjustments and corrections of errors there are in financial statements.

Similar conclusions about the connection between the growth of competition in the audit services market and reduced fees for audit older periods appear in the works of Maher et al. (1992) for the period 1977-1981., and Saunders et al. (1995) for the period 1985-1989.

In the context of further concentration of the supply of audit services due to the reduction of the largest accounting firms in the research of Dunn et al. (2013) and Gerakosand Syverson (2015), they proved that, with the growth of the overall market concentration, the Big 4 have a more equal share of the market than the Big 5 in the consolidation at all levels of analysis. They also established that the introduction of compulsory rotation of auditors or withdrawal from the market of one of the major players will result in an increase in fees for audit services.

As for the analyzed works on geographical identity, the existing research comprehensively considers the problem of competition in the audit services market at all levels. At the country level, the outlined problem was studied by Francis et al. (2013).

At the level of individual industries and local markets, often by the Fama-Frenchten classification approach, the audit competition problem was highlighted in the research of Hogan and Jeter (1999), Carson (2009), Mayhew and Wilkins (2003), and Numan and Willekens (2012). In particular, in recent work it is emphasized that a high concentration of audit services for the sectoral structure will not necessarily match the low intensity of competition.

At the level of cities and municipalities, the competition in the audit market was studied by Sanders et al. (1995), Francis et al. (2005), cities, and industrial cities - Dunn et al. (2011).

Regarding the research methodology, the majority of analyzed articles on the statistical description of market concentration has used traditional indicators for the market power of companies (market share of Big 4 and non-Big 4 auditors, the Herfindahl-Hirschman Index, and the Gini coefficient). 
Concentration proposals of dominant Big 4 companies and the Herfindahl-Hirschman Index, based on total sales of customers that are checked by each of the four companies, is used in the works of the Francis et al. (2013). The Herfindahl-Hirschman Index is calculated for a specific audit services market used in the logistics regression of Casterella et al. (2004). The HerfindahlHirschman Index was calculated in terms of payment for audit and calculated by the number of customers in the works of Gerakos and Syverson (2015).

Some authors use market concentration ratios, which are calculated on cumulative market share of the largest auditors in the field, in the works of Hogan and Jeter (1999).

Of particular note is the approach outlined in the work of Dunn et al. (2011), in which authors for the analysis of competition in the audit services market, in addition to traditional Ginny coefficient, also applied in the works of Quick and Wolz (1999), Abidin et al. (2008), and the Herfindahl-Hirschman Index adjusted in accordance with methodology of Minyard and Tabor (1991), also suggest using a new measure of the diversification of auditors according to the four largest customers in every industry.

In the context of the analyzed papers, it is necessary to emphasize the need for an integrated approach to the study of competition and its measurements in audit markets that are in their development stage, including Ukraine. The defining feature that characterizes the level of competition is the fact that companies entering the Big 4 market became a reason for its development toward a quasi-competitive market with a highly concentrated segment of the world's largest accountancy network, serving the needs of the largest companies in Ukraine, and a relatively competitive segment of national audit activity cooperating with its smaller companies.

Regarding the level of research, we propose that Ukraine choose the principle structuring of the audit market on geographical (administrative-territorial) units. The said principle corresponds not only to regions in terms of audit, which corresponds with the general level of economic activity and investment attractiveness, but also allows for distinguishing between segments of the market controlled by international audit companies and domestic companies.

In particular, a distinction of audit firms based on residence, the volume of services provided, and market position can be made clear at the regional level. Thus, Big 4 companies and international audit firms have major offices in Kyiv, unlike other regions and cities dominated by Ukrainian audit entities.

In addition, these companies are dominant in the audit services market. According to the Audit Chamber of Ukraine (2015), in 2015 , the 13 largest audit firms by volume of services provided for over UAH 10,000 accounted for $64.8 \%$ of the market.

A comparison of the competitive structure of the audit services market in Ukraine with other countries is generally consistent with a typical example of quasi-competitive markets where there are a significant concentration of Big 4 market representatives. Francis, Michaels, and Seavey. (2013) present data on market shares of Big 4 companies calculated by the number of customers in 42 countries. The maximum market share of Big 4 companies was recorded in Hungary at $93.0 \%$, and a minimum of $30.0 \%$ in Poland. The majority of EU countries had a very high market share of audit services owned by Big 4 companies: Norway - 74.0\%; Italy, Spain - 86.0\%; Luxembourg - 78.0\%; Denmark - 83.0\%. Meanwhile, the research of Gerakas J. and Syverson C. (2015) shows that the US market share of companies that do not belong to the Big 4, calculated in terms of audit compensation for $2000-2010$, ranged from $3.15 \%$ to $6.09 \%$.

Regarding the research methodology of market concentration seen in previous scientific works, it should be noted that there is a need to expand, especially with the number and positions of the indicators that characterize it.

\section{DATA AND RESEARCH METHODOLOGY}

Research was conducted based upon Audit Chamber of Ukraine data (http://www.apu.com.ua/pro-apu) over the period of 20072015. To assess competition on the Ukrainian audit market, the authors used the following indices by regions (26 Ukrainian regions were objects of research, including the temporarily occupied territories as far as the research period requires these data as well):

- number of reports submitted to the Audit Chamber of Ukraine (ACU);

- number of orders;

- actual volume of services provided;

- average costs of one order;

- number of orders per one entity;

- average income of one entity.

Values of these figures, generalized according to a simple average method (see Table 1), attest to a geographical imbalance of the audit services market. In particular, the figures of Kyiv and Kyiv Oblast exceed the results of the other regions several times, since international audit companies and their most economically active customers are concentrated there. It relates to such figures as number of orders; actual volume of services provided; average cost of one order; and average income of one person. 
Table 1. Average data as to growth indices of the Ukrainian audit services market over the period of 2007-2014

\begin{tabular}{|c|c|c|c|c|c|c|}
\hline Region & $\begin{array}{l}\text { Number } \\
\text { of reports, } \\
\text { submitted } \\
\text { to the ACU }\end{array}$ & $\begin{array}{l}\text { Number of } \\
\text { orders, pcs }\end{array}$ & $\begin{array}{c}\text { Actual volume } \\
\text { of services } \\
\text { provided, } \\
\text { thousand } \\
\text { hryvnias }\end{array}$ & $\begin{array}{l}\text { Average costs } \\
\text { of one order, } \\
\text { thousand } \\
\text { hryvnias }\end{array}$ & $\begin{array}{c}\text { Number of } \\
\text { orders per } \\
\text { one entity, } \\
\text { pcs }\end{array}$ & $\begin{array}{c}\text { Average } \\
\text { income of } \\
\text { one entity, } \\
\text { thousand } \\
\text { hryvnias }\end{array}$ \\
\hline AR of Crimea & 38.5 & $1,981.8$ & $6,805.4$ & 3.9 & 50.3 & 192.2 \\
\hline Vinnytsia Oblast & 29.0 & 681.6 & $4,402.2$ & 7.3 & 23.3 & 165.3 \\
\hline Volyn Oblast & 15.3 & 623.9 & $2,214.4$ & 4.1 & 40.3 & 148.3 \\
\hline Dnipropetrovsk Oblast & 120.3 & $3,493.3$ & $65,961.8$ & 20.1 & 29.1 & 587.7 \\
\hline Donetsk Oblast & 113.8 & $3,721.3$ & $32,021.3$ & 10.1 & 31.5 & 296.8 \\
\hline Zhytomyr Oblast & 26.4 & 910.8 & $4,476.6$ & 6.1 & 32.9 & 178.6 \\
\hline Zakarpattia Oblast & 20.9 & 445.4 & $3,749.1$ & 9.3 & 21.1 & 185.1 \\
\hline Zaporizhia Oblast & 76.4 & $2,208.8$ & $18,854.9$ & 9.2 & 28.9 & 260.7 \\
\hline Ivano-Frankivsk Oblast & 21.4 & 860.1 & $4,132.3$ & 4.9 & 41.0 & 204.9 \\
\hline Kyiv and Kyiv Oblast & 730.1 & $22,650.3$ & $888,343.3$ & 41.0 & 31.2 & $1,254.0$ \\
\hline Kirovohrad Oblast & 16.5 & 469.1 & $2,524.5$ & 6.4 & 27.6 & 159.5 \\
\hline Luhansk Oblast & 40.5 & $1,113.4$ & $5,138.1$ & 5.0 & 27.3 & 131.9 \\
\hline Lviv Oblast & 70.5 & $3,039.3$ & $25,087.1$ & 8.4 & 43.6 & 369.0 \\
\hline Mykolaiv Oblast & 41.3 & 586.9 & $4,429.1$ & 8.5 & 14.1 & 118.8 \\
\hline Odessa Oblast & 84.4 & $1,730.4$ & $20,696.4$ & 13.0 & 20.4 & 256.8 \\
\hline Poltava Oblast & 49.4 & $1,358.3$ & $6,296.5$ & 6.2 & 26.5 & 143.4 \\
\hline Rivne Oblast & 28.9 & 983.9 & $4,104.7$ & 4.8 & 33.9 & 146.1 \\
\hline Sevastopol & 15.5 & 680.8 & $3,711.2$ & 6.7 & 50.3 & 391.7 \\
\hline Sumy Oblast & 35.1 & 646.9 & $4,349.5$ & 7.6 & 18.2 & 134.5 \\
\hline Ternopil Oblast & 13.0 & 534.5 & $2,106.8$ & 4.3 & 41.1 & 166.9 \\
\hline Kharkiv Oblast & 149.6 & $4,190.9$ & $40,562.6$ & 11.8 & 26.9 & 289.6 \\
\hline Kherson Oblast & 26.8 & 989.1 & $6,071.6$ & 6.6 & 37.8 & 252.1 \\
\hline Khmelnytskyi Oblast & 21.8 & 661.9 & $3,860.6$ & 6.6 & 30.5 & 184.8 \\
\hline Cherkasy Oblast & 40.1 & 721.6 & $5,682.4$ & 8.8 & 17.6 & 146.6 \\
\hline Chernivtsi Oblast & 12.1 & 479.1 & $2,344.9$ & 5.5 & 38.8 & 195.8 \\
\hline Chernihiv Oblast & 20.6 & 590.4 & $3,628.6$ & 7.6 & 27.4 & 186.8 \\
\hline
\end{tabular}

Source: calculated by the authors according to Audit Chamber of Ukraine data.

Based on this data, the following hypothesis, tested in this research, results: The Ukrainian audit market is quasi-competitive, i.e., demonstrates elements of high concentration in the segment of large audit companies and low competition among small entities by regions.

Various methods and techniques of statistical analysis and assessment were applied in this research.

The first stage is a statistical confirmation of a hypothesis about the quasi competitiveness of the Ukrainian audit market. In order to prove affiliation of data groups to different general arrays, parametric and non-parametric methods are applied in statistics depending on whether or not data comply with normal distribution.

As far as the analyzed data do not comply with the normal distribution law (proved by Pearson's chi-criterion and Kolmogorov-Smirnov test, see Appendix A), it is appropriate to use only non-parametric methods. Given the peculiarity of the data array (26 groups), the Kruskal-Wallis test will be applied in the work.

Upon the condition of demonstrating that analyzed data groups (each region has its own data array) belong to different general arrays, we get indirect confirmation that the Ukrainian audit services market is not free-competitive. Respectively, in such a case we get confirmation of the basic hypothesis. 
While the previous statistical evaluations attest in favor of the hypothesis for the quasi competitiveness of the Ukrainian audit market, the next stage is quantitative assessment of the competitiveness level. For this purpose, it is suggested to apply not only the most important indices (concentration ratio, Herfindahl-Hirschman Index, Gini coefficient, and Lorentz curve), but other indices of market shares of companies that are not used very often in the study of the competitiveness of foreign audit services markets (Rosenbluth index, Lerner index, industry concentration coefficient, and entropy index).

Short characteristics of the given indices and their calculation formulas are given below (see Table 2).

Table 2. Main indices for assessment of market concentration

\begin{tabular}{|c|c|c|}
\hline Index name & Calculation & Characteristics \\
\hline Concentration ratio & $\begin{array}{l}\qquad C R n=\frac{R_{1}+R_{2}+\cdots+R_{n}}{R}, \\
\text { Where } C R_{n}-\text { partial concentration } \\
\text { ratio; } \\
n \text { - number of the largest market } \\
\text { participants; } \\
R_{i} \text { - market share controlled by i } \\
\text { participant; } \\
R \text { - market volume. }\end{array}$ & $\begin{array}{l}\text { Characterizes inequality on the market, reflecting position } \\
\text { of the largest companies. } \\
\text { Depending on the value of four-firm concentration ratio } \\
\text { (CR4) markets can be divided into } 4 \text { groups: } \\
\text { 1. Clear monopoly (CR4 } \approx 100 \% \text { ). } \\
\text { 2. Dominant companies }(40 \%<\text { CR4 }<60 \% \text { ). } \\
\text { 3. Limited oligopoly (CR4> } 60 \% \text { ). } \\
\text { 4. Effective competition (CR4 }<40 \% \text { ). }\end{array}$ \\
\hline $\begin{array}{l}\text { Herfindahl- } \\
\text { Hirschman Index } \\
\text { (HHI) }\end{array}$ & $\sum_{i=1}^{n}\left(\frac{R_{i}}{R}\right)^{2}$ & $\begin{array}{l}\text { Used to assess level of industry monopolization. } \\
\text { Varies within the range of }[0 ; 1] \text { : } \\
\text { 1) } 0 \text { - minimum concentration; } \\
\text { 2) from } 0 \text { to } 0.1 \text { - low concentration level; } \\
\text { 3) from } 0.10 \text { to } 0.18 \text { - mean concentration level; } \\
\text { 4) over } 0.18 \text { - high concentration level**. }\end{array}$ \\
\hline Lerner index & $\begin{array}{c}L=\frac{P-M C}{P} \\
P-\text { price per product unit; } \\
M C-\text { marginal costs, related to } \\
\text { manufacturing of additional product } \\
\text { unit. }\end{array}$ & $\begin{array}{l}\text { Calculation of a value, by which the price exceeds } \\
\text { marginal costs, can provide the information on degree of } \\
\text { market monopolization. The more the gap is between P and } \\
\text { MC, the higher the market monopolization degree is. } \\
\text { Lerner index varies within the range of [0; } 1] \text {. The more } \\
\text { Lerner index value approaches to } 1 \text {, the higher the market } \\
\text { monopolization degree is. Accordingly, perfect competition } \\
\text { implies a Lerner index being equal to } 0 \text {. }\end{array}$ \\
\hline Rosenbluth index & $\frac{1}{=1}\left(i \times R_{i}\right)-1$ & $\begin{array}{l}\text { Enables consideration of a range of market participants } \\
\text { when assessing its concentration. } \\
\text { Rosenbluth index value varies within the range of [1/n; } 1] \text {. } \\
\text { The more the coefficient is, the more market monopolization is. }\end{array}$ \\
\hline $\begin{array}{l}\text { Industry } \\
\text { concentration } \\
\text { coefficient }\end{array}$ & $C C I=R_{1}+\sum_{i=2} R_{i}^{2} \times\left(1+\left(1-R_{i}\right)\right)$ & $\begin{array}{l}\text { Enables assessing the correlation between market share } \\
\text { fluctuation and absolute significance of the largest market } \\
\text { entity's share. } \\
\text { Industry concentration value varies within the range of } \\
{[0 ; 1] \text {. The more the coefficient is, the higher the market }} \\
\text { monopolization is. }\end{array}$ \\
\hline Entropy index & $E=\frac{1}{n} \sum_{i=1}^{n} R_{i} \times \ln \frac{1}{R_{i}}$ & $\begin{array}{l}\text { This index, by means of reducing the significance of } \\
\text { market shares of large market entities, enables increasing } \\
\text { the significance of market shares of small market entities. } \\
\text { The more the entropy index is, the higher economic } \\
\text { uncertainty is and the lower the probability is to establish } \\
\text { monopoly or oligopoly. }\end{array}$ \\
\hline Gini coefficient & $G=\frac{\sum_{i=1}^{n} \sum_{j=1}^{n}\left|R_{i}-R_{j}\right|}{2 n^{2} \bar{R}}$ & $\begin{array}{l}\text { Gini coefficient is a quantitative interpretation of Lorentz } \\
\text { curve. } \\
\text { It varies within the range from } 0 \text { to } 1 \text {. The larger the } \\
\text { Gini coefficient, the larger the inequality of distribution of } \\
\text { market shares between market participants is and, thus, the } \\
\text { concentration level on the market is higher. }\end{array}$ \\
\hline
\end{tabular}

*division is based on the calculations Naldi, Flamini (2014), p. 5.

** division is based on the calculations Hirschey (2008), p. 529. 
In addition, for a visual (graphic) interpretation of the inequality level a Lorentz curve is used - a diagram of cumulative shares of the companies on the market (axis $\mathrm{X}$ ) and cumulative market volume (axis $\mathrm{Y}$ ).

In theoretical terms, absolutely equal market distribution is characterized by a bisector coming out of the coordinate origin point. The higher the deviation of empiric distribution is from the theoretical one, the higher the degree of inequality available on the market is.

\section{EMPIRICAL RESULTS}

\section{Kruskal-Wallis test}

The results of the Kruskal-Wallis statistical test are outlined in Appendix B.

According to calculation results, analyzed data belong to different general aggregates, which is indirect evidence in favor of the hypothesis of the quasi-competitiveness of the Ukrainian audit market.

\section{Concentration indices}

The results of concentration indices analysis (Concentration ratio (CR1), Concentration ratio (CR4), Herfindahl-Hirschman Index ( $\mathrm{HHI})$, Rosenbluth index, Industry concentration coefficient (CCI), Entropy index, Gini coefficient, and Lerner Index) are given in the Appendix $C$.

The degree of inequality in the Ukrainian audit market is represented in a graphic by means of a Lorentz curve based on the selected data (Appendix D).

Table 3 was developed to generalize the results obtained.

\section{Table 3. Generalization of results of concentration indices analysis of the Ukrainian audit market (as of the end of 2014)}

\begin{tabular}{|c|c|c|c|}
\hline Parameter & $\begin{array}{l}\text { Number of reports submitted } \\
\text { to the } A C U\end{array}$ & Number of orders & $\begin{array}{l}\text { Actual volume of services } \\
\text { rendered, thousand hryvnias }\end{array}$ \\
\hline Concentration ratio (CR1) & Dominant companies & Dominant companies & Dominant companies \\
\hline Concentration ratio (CR4) & Dominant companies & Dominant companies & Dominant companies \\
\hline $\begin{array}{l}\text { Herfindahl-Hirschman } \\
\text { Index (HHI) }\end{array}$ & High concentration level & High concentration level & High concentration level \\
\hline Rosenbluth index & Low monopolization level & Low monopolization level & $\begin{array}{l}\text { Moderate monopolization } \\
\text { level }\end{array}$ \\
\hline $\begin{array}{l}\text { Industry concentration } \\
\text { coefficient (CCI) }\end{array}$ & Moderate concentration level & Moderate concentration level & High concentration level \\
\hline Entropy index & $\begin{array}{l}\text { High probability of monopoly } \\
\text { or oligopoly }\end{array}$ & $\begin{array}{l}\text { High probability of monopoly } \\
\text { or oligopoly }\end{array}$ & $\begin{array}{l}\text { High probability of monopoly } \\
\text { or oligopoly }\end{array}$ \\
\hline Gini coefficient & Moderate concentration level & Moderate concentration level & High concentration level \\
\hline Lorentz curve & $\begin{array}{c}\text { Fundamental inequality on } \\
\text { the market }\end{array}$ & $\begin{array}{c}\text { Fundamental inequality on } \\
\text { the market }\end{array}$ & $\begin{array}{l}\text { Fundamental inequality on the } \\
\text { market }\end{array}$ \\
\hline Lerner index & \multicolumn{3}{|c|}{ High level of market monopolization } \\
\hline
\end{tabular}

According to the results of the analysis, which implied a number of indices of market concentration and Kruskal-Wallis test regarding Ukraine's audit services market in regional aspects, Ukraine's audit market is non-uniform in terms of its structure. Available audit entities are combined into two segments: a highly concentrated segment of large companies, represented by the leading audit companies and a few representatives of Ukrainian audit business, registered in Kyiv and Kyiv Oblast, as well as by a segment of small national audit entities activity broadly represented in other regions.

Dominant companies on the market, considering national and international legal and ethical norms, market conjuncture, and customers' needs, have to demonstrate certain signs of competitive actions with a view to adherence to the correlation: 'quality of services - labor input of services - audit reward - reliability of confirmable financial statements.' 
Small audit companies, aimed at servicing needs of medium and small businesses, first of all, demonstrate signs of price competition regardless of the quality of the services rendered.

In addition, analysis of Ukraine's audit services market, considering the combination of high-level concentration in its most profitable segment with separate signs of competitive behavior, allows for it to be regarded as quasi-competitive. Accordingly, the suggested hypothesis can be assumed as proved.

\section{CONCLUSIONS AND RECOMMENDATIONS}

The issue of studying fair competition in the audit services market becomes relevant during a post-crisis period for the purposes of ensuring qualitative audits of financial statements of systemically significant companies along with maintenance of audit practice transparency and prevention of its further consolidation. The importance of these issues is emphasized by the respective regulatory bodies all over the globe: European Commission (EC Green Paper, Directive 2014/56/EC), Competition Commission and House of Lords Economic Affairs Committee, CIMA UK, Public Company Accounting Oversight Board, US Government Accountability Office, and supranational organizations like ACCA and OECD.

Contributions of scientists in the area of audit competition is diverse both in terms of research (establishing relationships between the level of market concentration and parameters of rendering audit services) and chosen methodology and research level.

Research by geography (regions) provides the possibility to compare the competition level in the audit services market with the level of development of audit activity and general economic activity of Ukrainian regions, as well as to differentiate them in terms of a residency feature of audit entities.

In addition to traditional methods of studying market concentration (concentration index, Gini coefficient, Lorentz curve, Herfindahl-Hirschman Index), a number of additional indices were calculated (Rosenbluth, Lerner indices, industry concentration coefficient, and entropy index) in terms of the number of reports submitted to the ACU, the number of orders, the actual volume of services rendered, the average costs of one order, the number of orders per one entity, and the average income per one entity.

In addition, the Kruskal-Wallis test made it possible to prove that the analyzed data arrays based on figures by region belong to different aggregates, which is an indirect confirmation of the non-uniformity of the Ukrainian audit services market.

The results of applying nonparametric methods conforms to the calculations of the given coefficients and make it possible to prove the hypothesis of the quasi-competitive nature of the Ukrainian audit services market with the prevalence of a highly concentrated segment of the largest global audit networks (concentrated in Kyiv and Kyiv Oblast), which serve the needs of the largest companies of Ukraine, and a relatively competitive segment of national audit entities that cooperate with smaller companies.

Along with that, a controversial situation occurs in the field of governing audit activity with limiting conditions, established by subordinate legislation of the Cabinet of Ministers of Ukraine and its departmental bodies in favor of a separate category of audit entities, only proves the results obtained of calculations and requires urgent measures.

Based on the quasi-competitive nature of the Ukrainian audit services market and destructive conditions that restrict its development, the following recommendations are given for its regulators (the Ministry of Finance of Ukraine and the Audit Chamber of Ukraine) in the context of European integration processes as to stabilize the market and increase the level of competition in the market:

- Cancel existing discriminatory conditions of engaging audit companies into fulfillment of tasks of providing justified and limited confidence according to key International standards of quality control, audit, inspection, other provision of confidence, and related services (primarily in the segments of the largest state companies and companies providing financial services);

- Prohibit state administration bodies (Cabinet of Ministers of Ukraine, National Commission for State Regulation of Financial Services Markets) to establish limiting covenants and providing preferences (obvious or not) in favor of separate participants of audit market services, especially international audit companies, and separately of the Big 4 segment, which already have reputational and infrastructural privileges given the global scale of requirements for audit. In this regard, activity of the Audit Chamber of Ukraine requires reformation as to:

- Expand its powers in the field of control and supervision on the audit services market, especially in the context of rendering them in separate industries and fields of activity (state sector, financial markets, banking systems); 
- Develop coordination activities of the Audit Chamber of Ukraine as to ensuring a competitive environment on the audit services market with respective industry regulators (National Bank of Ukraine, National Commission for State Regulation of Financial Services Markets, National Securities and Stock Market Commission, Anti-Monopoly Committee of Ukraine);

- Promote fair tenders for audit committees of audit companies' customers. The Audit Chamber of Ukraine and industry regulators should develop recommendations as to the procedure of conducting such tenders when engaging auditors to perform tasks based on the principles of transparency and openness, the goal of which to limit unfair price competition, price dumping, avoidance of rotation of audit companies, and conflict of interests according to the procedure specified by the International Federation of Accountants, Directives 2014/56/EC and Regulations (16 April 2014);

- Strengthen control of the Anti-Monopoly Committee of Ukraine over audit entities by developing legislative mechanisms and efficiency of its regulatory activity on the audit services market. Moreover, activity of the Anti-Monopoly Committee of Ukraine on the audit services market should be necessarily adjusted to the measures of an independent body of civil supervision of audit entities, establishment of which is urgent based on the necessity for fulfilling requirements of Directive 2014/56/EC and Regulation (16 April 2014);

- Contribute to the development of the national audit services market with an emphasis on improvement of the quality of audit services, the level of qualification and education of their employees according to the standards of audit activity (International standards of quality control, audit, supervision, other provision of confidence and related services), the Code of Ethics of Professional Accountants, and the International Standards of Education of Professional Accountants of the International Federation of Accountants. In particular, the actualization of education programs for preparing auditors and qualification programs for their examination and training need to be required to be in line with the requirements of the documents mentioned above. Distribution of international certification programs in the system of preparing auditors can be singled out into a separate direction of developing and maintaining an appropriate level of qualification of the national auditors and absolute quality of services rendered.

\section{References}

- Abidin S., Beattie V., Goodacre A. (2008). Audit Market Structure, Fees and Choice following the Andersen Break-up: Evidence from the U.K., British. https://doi.org/10.2139/ssrn.1096464

- ACCA (2011). Audit under fire: a review of the post-financial crisis inquiries. Available at: http://www.accaglobal. com/content/dam/acca/global/PDF-technical/audit-publications/pol-af-auf.pdf

- Baumol W.J. et al. (1982). Willing Contestable Markets and the Theory of Industry Structure, New York: Harcourt Brace Jovanovich, $510 \mathrm{p}$.

- Boone J.P., Khuranaet I.K., Raman K.K. (2012). Audit Market concentration and Auditor Tolerance for Earnings Management. Contemporary Accounting Research, Vol. 29, No. 4, pp. 1171-1203.

https://doi.org/10.1111/j.1911-3846.2011.01144.x

- Carson E. (2009). Industry specialization by global audit firm networks. Accounting Review, No. 84, pp. 355-382. https://doi.org/10.2308/accr.2009.84.2.355

- Casterella J., Francis J., Lewis B., Walker P. (2004). Auditor industry specialization, client bargaining power and audit pricing. Auditing: A Journal of Practice \& Theory, Vol. 23, No. 1, pp. 123-140. https://doi.org/10.2308/aud.2004.23.1.123

- CIMA (2010). Auditors: market concentration and their role consultation response. Available at: http://www.cimaglobal.com/Documents/Insightdocs/HoL\%20Auditor\%20report\%20September\%202010.pdf

- Competition Commission (2013). Statutory audit services for large companies market investigation: a report on the provision of statutory audit services to large companies in the UK.

- Directive 2014/56/EU of the European Parliament and of the Council of 16 April 2014 amending Directive 2006/43/EC on statutory audits of annual accounts and consolidated accounts. Available at: http://eur-lex.europa.eu/legal-content/ EN/TXT/?uri=celex\%3A32014L0056

- Doogar R. and Easley R. (1998). Concentration without Di_erentiation: A New Look at the Determinants of Audit Market Concentration. Journal of Accounting and Economics, No. 25, pp. $235-253$. https://doi.org/10.1016/S0165-4101(98)00027-5

- Dunn K., Kohlbeck M., Mayhew B.W. (2011). The Impact of the Big 4 Consolidation on Audit Market Share Equality. Auditing: A Journal of Practice \& Theory, Vol. 30, No. 1, pp. 49-73. https://doi.org/10.2308/aud.2011.30.1.49 
- Francis J., Michas P., Seavey S. (2013). Does Audit Market Concentration Harm the Quality of Audited Earnings? Evidence from Audit Markets in 42 Countries. Contemporary Accounting Research, Vol. 30 No. 1, pp. 325-355. https://doi.org/10.1111/j.1911-3846.2012.01156.x

- Francis J., Reicheltet K., Wang D. (2005). The Pricing of National and City-Specific Reputations for Industry Expertise in the U.S. Audit Market. The Accounting Review, Vol. 80, pp. 113-136.

- Gerakos J., Syverson C. (2015). Competition in the Audit Market: Policy Implications. Chicago Booth Research Paper, No. 13-63. https://doi.org/10.1111/1475-679X.12087

- Government Accountability Office (2003). Public accounting firms: mandated study on consolidation and competition. GAO, Washington DC.

- Government Accountability Office (2008). Audits of public companies: Continued concentration in audit markets for large public companies does not call for immediate action. GAO, Washington DC.

- Hirschey M. (2008). Fundamentals of Managerial Economics. Cengage Learning, 816 p.

- Hogan C., Jeter D. (1999). Industry specialization by auditors. Auditing: A Journal of Practice and Theory, Vol., No. 18, pp. 1-17. https://doi.org/10.2308/aud.1999.18.1.1

- House of Lords Select Committee on Economic Affairs (2010). Auditors: Market concentration and their role. Available at: http://www.publications. parliament.uk/pa/ld201011/Idselect/Ideconaf/119/119.pdf

- Maher M., Tiessen P., Colson R., Broman A. (1992). Competition and Audit Fees. Accounting Review, Vol. 67, No. 1, pp. 199-211.

- Minyard D., Tabor R. (1991). The effect of Big Eight mergers on auditor concentration. Accounting Horizons, Vol. 5, pp. 79-90.

- Naldi M., Flamini M. (2014). The CR4 index and the interval estimation of the Herndahl-Hirschman Index: an empirical comparison. Available at: https://hal.archives-ouvertes.fr/hal-01008144

- Newton N., Wang D., Wilkins M.S. (2013). Does a Lack of Choice Lead to Lower Audit Quality? Evidence from Auditor Competition and Client Restatements. Auditing: A Journal of Practice \& Theory, Vol. 32, No. 3, pp. 31-67. https://doi.org/10.2308/ajpt-50461

- Numan W., Willekens M. (2012). An empirical test of spatial competition in the audit market, Journal of Accounting \& Economics, Vol., 53, No. 1-2, pp. 450-465.

- OECD (2009, 2010). Policy Roundtables Competition and Regulation in Auditing and Related Professions.

- Ogorodnikova T., Sergeyeva S. (2013). Theory of quasi-competitive markets. Ekonomika 2.0. Available at: http://econ2.ru/blogs/problemy-obrazovanija/teorija-kvazikonkurentnyh-rynkov.html

- Oxera (2006). Competition and Choice in the UK Audit Market, Prepared for Department of Trade and Industry and Financial Reporting Council, Oxford, UK: Oxera Consulting Ltd. Available at: http://www.oxera.com/getmedia/6f57bebe-ad074e01-953f-687f170319d2/Competition-and-choice-in-the-UK-audit-market\%E2\%80\%94executive-summary_1.pdf.aspx

- Petrakov A. (2013).Theory of quasi-competitive markets and audit services market: identification problems. Visnyk Chernihivskoho derzhavnoho tekhnolohichnoho universytetu, No. 3, pp. 248-258.

- Quick R., Wolz M. (1999). Concentration on the German audit market-An empirical analysis of the concentration on the German market for stock corporation audits, International Journal of Auditing, Vol. 3, pp. 175-189.

- Redko O. (2009). The methodology and organization of professional audit in Ukraine. Status and Prospects: avtoref. dys. d-ra ekon. nauk: 08.00.2009. Derzh. kom. statystyky Ukrainy, Derzh. akad. statystyky, obliku ta audytu.

- Sanders G., Arthur A., Leonet K. (1995). Municipal Audit Fees: has Increased Competition Made a Difference? Auditing: A Journal of Practice \& Theory, Vol. 14, No. 1, pp. 105-114.

- Securities and Exchange Commission. Speech by SEC Chairman: Remarks Before the 2005 AICPA National Conference on Current SEC and PCAOB Developments by Chairman Christopher Cox U.S., Washington D.C.

- U.S. Treasury (2006). Remarks by Treasury Secretary Henry M. Paulson on the competitiveness of U.S. capital markets - Economic Club of New York, New York, NY. Available at: http://www.ustreas.gov/press/releases/hp174.htm 


\section{Appendix A}

Table A1. Check of input data to correspond the normal distribution

Parameter
Xi - square
Critical value of
Xi-square distribution
( $p=0.95)$
Null hypothesis
$d$ Kolmogorov-Smirnov
Critical value of
Kolmogorov-Smirnov
criteria
( $p=0.95, n=208)$
Null hypothesis
Conclusion

\begin{tabular}{|c|c|c|c|c|c|}
\hline $\begin{array}{c}\text { Number } \\
\text { of reports } \\
\text { provided by } \\
\text { ACU }\end{array}$ & $\begin{array}{l}\text { Number } \\
\text { of orders, } \\
\text { units }\end{array}$ & $\begin{array}{c}\text { Actual volume of } \\
\text { provided service, } \\
\text { thsd UAH }\end{array}$ & $\begin{array}{c}\text { Average costs } \\
\text { per order, thsd } \\
\text { UAH }\end{array}$ & $\begin{array}{l}\text { Number of } \\
\text { orders per } \\
\text { subject, units }\end{array}$ & $\begin{array}{c}\text { Average } \\
\text { income per } \\
\text { subject, thsd } \\
\text { UAH }\end{array}$ \\
\hline 361.60 & 509.76 & 644.49 & 112.69 & 17.68 & 136.65 \\
\hline 5.99 & 11.07 & 7.81 & 11.07 & 7.81 & 5.99 \\
\hline Rejected & Rejected & Rejected & Rejected & Rejected & Rejected \\
\hline 0.3036 & 0.309 & 0.3975 & 0.1866 & 0.054 & 0.1929 \\
\hline 0.0943 & 0.0943 & 0.0943 & 0.0943 & 0.0943 & 0.0943 \\
\hline Rejected & Rejected & Rejected & Rejected & Not rejected & Rejected \\
\hline \multicolumn{6}{|c|}{ Data is not normally distributed } \\
\hline
\end{tabular}




\section{Appendix B}

Table B1. Results of Kruskal-Wallis test

\begin{tabular}{|c|c|c|c|c|c|c|}
\hline & $\begin{array}{c}\text { Number } \\
\text { of reports } \\
\text { provided by } \\
\text { ACU }\end{array}$ & $\begin{array}{c}\text { Number of } \\
\text { orders, units }\end{array}$ & $\begin{array}{c}\text { Actual volume } \\
\text { of provided } \\
\text { service, thsd } \\
\text { UAH }\end{array}$ & $\begin{array}{c}\text { Average cost } \\
\text { per order, thsd } \\
\text { UAH }\end{array}$ & $\begin{array}{c}\text { Number of } \\
\text { orders per } \\
\text { subject, units }\end{array}$ \\
\hline $\begin{array}{c}\text { Average } \\
\text { income per } \\
\text { subject, thsd } \\
\text { UAH }\end{array}$ \\
\hline Corrected H & 260.30 & 232.56 & 262.04 & 161.35 & 210.77 & 177.02 \\
\hline $\begin{array}{c}\text { Degrees of } \\
\text { freedom }\end{array}$ & 24 & 24 & 24 & 24 & 24 & 24 \\
\hline Volume of P: & 0.000000 & 0.000000 & 0.000000 & 0.000000 & 0.000000 & 0.000000 \\
\hline Critical value & 36.41 & 36.41 & 36.41 & 36.41 & 36.41 & 36.41 \\
\hline Null hypothesis & Rejected & Rejected & Rejected & Rejected & Rejected \\
\hline
\end{tabular}




\section{Appendix C}

Table C1. Concentration Indexes

(using Number of reports provided by ACU index as an example)

\begin{tabular}{|c|c|c|c|c|c|c|c|c|}
\hline Parameter & 2007 & 2008 & 2009 & 2010 & 2011 & 2012 & 2013 & 2014 \\
\hline Concentration ratio (CR1) & $35.15 \%$ & $37.02 \%$ & $38.25 \%$ & $39.36 \%$ & $41.24 \%$ & $41.14 \%$ & $41.67 \%$ & $44.34 \%$ \\
\hline Concentration ratio (CR4) & $57.46 \%$ & $58.08 \%$ & $59.15 \%$ & $59.77 \%$ & $61.38 \%$ & $60.91 \%$ & $61.64 \%$ & $63.99 \%$ \\
\hline $\begin{array}{l}\text { Herfindahl-Hirschman index } \\
\text { (HHI) }\end{array}$ & 0.15 & 0.16 & 0.17 & 0.18 & 0.19 & 0.19 & 0.20 & 0.22 \\
\hline Rosenbluth index & 0.10 & 0.10 & 0.10 & 0.10 & 0.11 & 0.11 & 0.11 & 0.12 \\
\hline $\begin{array}{l}\text { Sectorial Concentration index } \\
\text { (SCI) }\end{array}$ & 0.41 & 0.42 & 0.43 & 0.44 & 0.46 & 0.46 & 0.46 & 0.49 \\
\hline Entropy index & $9.81 \%$ & $9.67 \%$ & $9.55 \%$ & $9.46 \%$ & $9.28 \%$ & $9.30 \%$ & $9.23 \%$ & $8.87 \%$ \\
\hline Gini coefficient & 0.44 & 0.44 & 0.45 & 0.45 & 0.47 & 0.46 & 0.47 & 0.50 \\
\hline
\end{tabular}

Table C2. Concentration indexes (using Number of orders index as an example)

\begin{tabular}{|c|c|c|c|c|c|c|c|c|}
\hline Parameter & 2007 & 2008 & 2009 & 2010 & 2011 & 2012 & 2013 & 2014 \\
\hline Concentration ratio (CR1) & $34.83 \%$ & $39.12 \%$ & $37.21 \%$ & $38.36 \%$ & $43.37 \%$ & $43.36 \%$ & $44.81 \%$ & $47.82 \%$ \\
\hline Concentration ratio (CR4) & $58.01 \%$ & $60.90 \%$ & $59.78 \%$ & $58.14 \%$ & $61.21 \%$ & $61.41 \%$ & $62.78 \%$ & $65.04 \%$ \\
\hline $\begin{array}{l}\text { Herfindahl-Hirschman index } \\
\text { (HHI) }\end{array}$ & 0.15 & 0.18 & 0.17 & 0.17 & 0.21 & 0.21 & 0.22 & 0.25 \\
\hline Rosenbluth index & 0.10 & 0.10 & 0.10 & 0.10 & 0.11 & 0.11 & 0.12 & 0.13 \\
\hline $\begin{array}{l}\text { Sectorial Concentration index } \\
\qquad(\mathrm{SCl})\end{array}$ & 0.41 & 0.44 & 0.43 & 0.43 & 0.48 & 0.48 & 0.49 & 0.52 \\
\hline Entropy index & $9.82 \%$ & $9.45 \%$ & $9.57 \%$ & $9.61 \%$ & $9.02 \%$ & $8.99 \%$ & $8.79 \%$ & $8.46 \%$ \\
\hline Gini coefficient & 0.44 & 0.46 & 0.46 & 0.46 & 0.48 & 0.49 & 0.51 & 0.53 \\
\hline
\end{tabular}

Table C3. Concentration indexes

(using Actual volume of provided service index as an example)

\begin{tabular}{|c|c|c|c|c|c|c|c|c|}
\hline Parameter & 2007 & 2008 & 2009 & 2010 & 2011 & 2012 & 2013 & 2014 \\
\hline Concentration ratio (CR1) & $68.01 \%$ & $74.77 \%$ & $77.84 \%$ & $76.18 \%$ & $76.25 \%$ & $75.33 \%$ & $74.74 \%$ & $79.39 \%$ \\
\hline Concentration ratio (CR4) & $82.13 \%$ & $86.61 \%$ & $88.14 \%$ & $87.73 \%$ & $87.92 \%$ & $87.65 \%$ & $88.53 \%$ & $89.54 \%$ \\
\hline $\begin{array}{l}\text { Herfindahl-Hirschman index } \\
\text { (HHI) }\end{array}$ & 0.47 & 0.57 & 0.61 & 0.59 & 0.59 & 0.57 & 0.57 & 0.64 \\
\hline Rosenbluth index & 0.25 & 0.32 & 0.36 & 0.35 & 0.36 & 0.35 & 0.37 & 0.42 \\
\hline $\begin{array}{l}\text { Sectorial Concentration index } \\
\qquad(\mathrm{SCl})\end{array}$ & 0.70 & 0.76 & 0.79 & 0.77 & 0.78 & 0.77 & 0.76 & 0.80 \\
\hline Entropy index & $5.72 \%$ & $4.78 \%$ & $4.32 \%$ & $4.53 \%$ & $4.48 \%$ & $4.61 \%$ & $4.58 \%$ & $3.99 \%$ \\
\hline Gini coefficient & 0.67 & 0.72 & 0.75 & 0.74 & 0.74 & 0.74 & 0.75 & 0.77 \\
\hline
\end{tabular}

Table C4. Lerner index

\begin{tabular}{|c|c|c|c|c|c|c|c|c|}
\hline Year & 2007 & 2008 & 2009 & 2010 & 2011 & 2012 & 2013 & 2014 \\
\hline On average, in Ukraine & 0.94 & 0.92 & 0.90 & 0.90 & 0.91 & 0.92 & 0.91 & 0.91 \\
\hline
\end{tabular}




\section{Appendix D}

Figure D1. Lorenz curve based on the Number of reports provided by ACU parameter

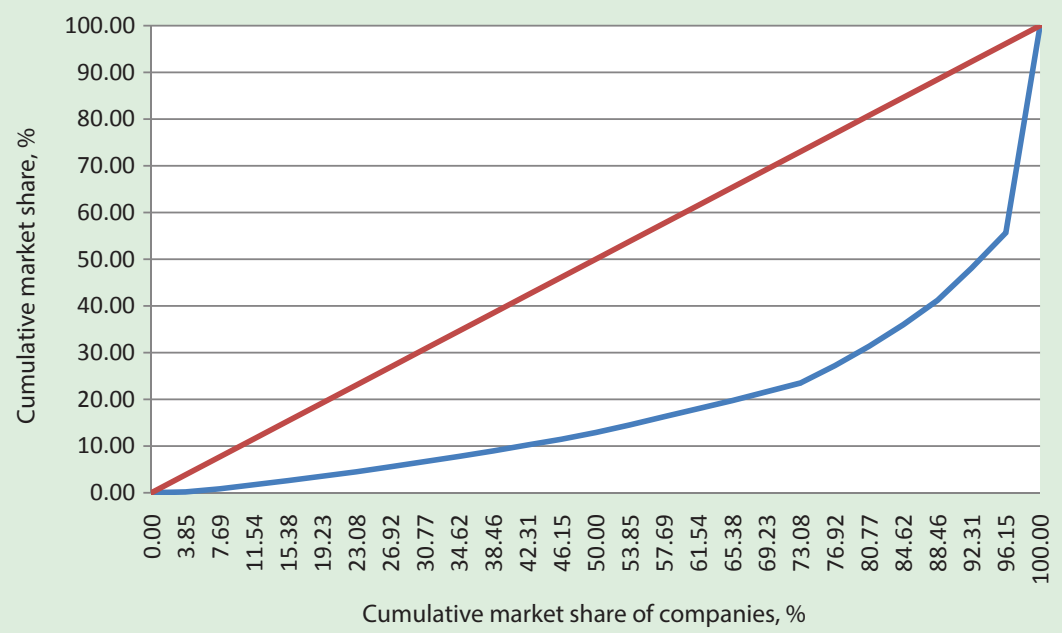

Figure D2. Lorenz curve based on the Number of orders parameter

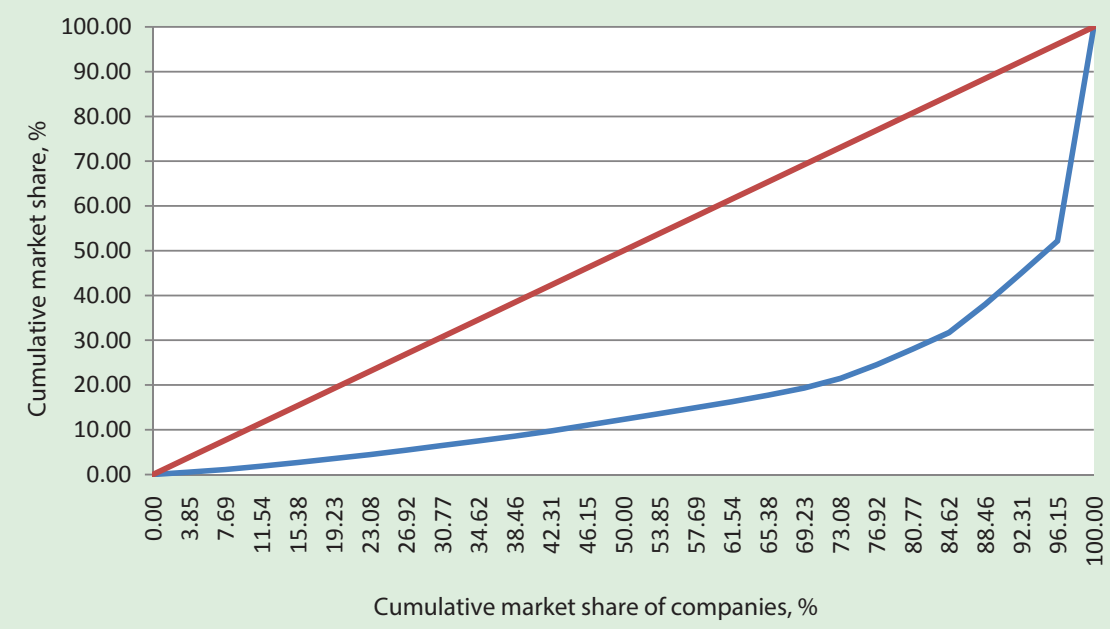

Figure D3. Lorenz curve based on the Actual volume of provided service parameter

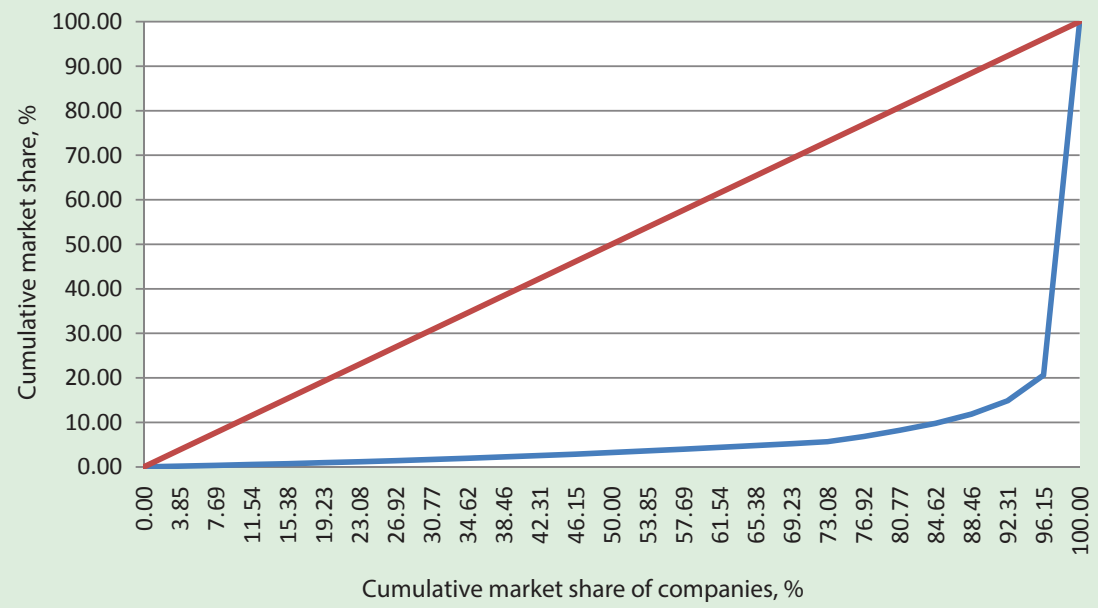

